\title{
ANALISIS PEMAHAMAN MAHASISWA TERHADAP TEOREMA DAN SIFAT-SIFAT ALJABAR BILANGAN REAL
}

\author{
Annisa Safriani ${ }^{1}$, Suherdi ${ }^{2}$, Sendi Andika ${ }^{3}$, Ramadhani ${ }^{4}$ \\ 1,2,3,4Universitas Muslim Nusantara AI Washliyah Medan \\ annisa.safriani123@gmail.com
}

\begin{abstract}
ABSTRAK Penelitian ini bertujuan untuk mengetahui pemahaman mahasiswa terhadap teorema sifat-sifat aljabar. Pendekatan yang digunakan dalam penelitian ini adalah pendekatan deskriptif. Subjek penelitian ini adalah mahasiswa Universitas Muslim Nusantara Al-Washliyah Medan Program Studi Pendidikan Matematika Semester 6A yang berjumlah sebanyak 37 orang mahasiswa. Instrumen dalam penelitian ini berupa tes sebanyak 3 butir soal. Sumber data yang dipergunakan dalam penelitian analisis ini yaitu hasil tes responden terkait pembuktian matematik dan sumber responden yang dipilih didasarkan pada kriteria yang dipenuhinya. Kemudian hasil penelitian ini memperoleh kesimpulan bahwa, pemahaman mahasiswa terhadap teorema dan sifat-sifat aljabar bilangan real dilihat dari segi aspek kesesuaian data memiliki persentase sebesar 60,20\%, aspek prosedur yang tepat sebesar $45,33 \%$, aspek kelengkapan data sebesar $52,76 \%$, dan aspek kesimpulan akhir memiliki persentase sebesar 59,46
\end{abstract}

Kata-kata Kunci: Analisis Real, Pemahaman, Teorema dan Sifat Aljabar Bilangan Real.

\section{PENDAHULUAN}

Pendidikan merupakan salah satu elemen penting dalam kemajuan suatu bangsa. Bangsa yang ingin maju maka harus memajukan kualitas pendidikan dan tenaga pendidiknya terlebih dahulu. Karena melalui pendidikan dan tenaga pendidik yang baik individu dapat memperoleh ilmu, pengetahuan, dan keterampilan yang akan berdampak pada kemampuan pikiran, berusaha dan penguasaan teknologi. Dengan pendidikan dan tenaga pendidik yang baik setiap individu dapat memenuhi segala kebutuhan dengan segala keterampilan yang dimilikinya. Oleh karena itu perlunya mempersiapkan tenaga-tenaga pendidik atau calon guru yang handal dan professional, karena fungsi guru menurut Undang-Undang No. 14 Tahun 2005 tentang Guru dan Dosen adalah meningkatkan mutu pendidikan nasional.

Pada tingkat universitas, mahasiswa pendidikan matematika atau calon tenaga pengajar dituntut akan pemahaman konsep-konsep matematis dalam mata kuliahnya, terutama dalam mata kuliah analisis real. Analisis real merupakan mata kuliah wajib program studi pendidikan matematika. Dan mata kuliah ini biasanya berbobot 3 sks atau 4 sks, tergantung pada masing-masing perguruan tinggi. Pada 
mata kuliah analisis real, mahasiswa dihadapkan pada teorema-teorema yang ada. Mahasiswa dituntut untuk dapat menyusun pembuktian dan memvalidasi bentuk pembuktian dari setiap teorema yang ada. Hal ini sejalan dengan pendapat Weber (dalam Sari \& Waluyo, 2017): "Kemampuan mengkonstruksi bukti sangat penting bagi mereka yang berada pada bidang matematika". Dan menurut Hanna dan Villiers (dalam Ainur \& Darmaningsih, 2017): "Bukti berperan dalam menjelaskan kebenaran pernyataan matematika". Oleh karena itu, pemahaman mahasiswa mengenai teorema sangat penting bagi mahasiswa program studi pendidikan matematika.

Namun seperti yang diungkapkan Mutaqin (dalam Perbowo \& Pradipta, 2017): "Mata kuliah analisis real termasuk dalam katagori mata kuliah yang dinilai sangat sulit bagi mahasiswa pendidikan matematika". Hal ini dikarenakan dalam perkuliahan mahasiswa tidak banyak bersinggungan dengan proses analisis teorema yang ada dalam matematika. Dengan melihat perkembangan pembelajaran analisis real dan berbagai tingkat pemahaman dari diri mahasiswa maka peneliti melakukan penelitian untuk menganalisis pemahaman mahasiswa terhadap teorema-teorema matematika. Penelitian ini dilakukan untuk mengetahui pemahaman mahasiswa terhadap teorema-teorema sifat aljabar bilangan real.

\section{METODE PENELITIAN}

Penelitian ini adalah penelitian kualitatif dimana data yang diperoleh berupa katakata tertulis atau lisan dari orang-orang dan perilaku yang dapat diamati (Margono, 2010). Pendekatan yang digunakan dalam penelitian ini adalah pendekatan deskriptif. Penelitian ini dilaksanakan di Universitas Muslim Nusantara Al-Washliyah Medan pada Program Studi Pendidikan Matematika, Semester 6. Waktu penelitian dilakukan pada semester genap Tahun Akademik 2019/ 2020. Subjek penelitian ini adalah mahasiswa Program Studi Pendidikan Matematika Semester 6A yang berjumlah sebanyak 37 orang mahasiswa.

Penelitian ini meliputi analisis pemahaman mahasiswa akan teorema-teorema sifatsifat aljabar bilangan real. Data pemahaman akan teorema-teorema sifat-sifat aljabar bilangan real ini diperoleh melalui tes terkait penyusunan pembuktian matematik. Instrumen tes pembuktian matematik ini diberikan oleh dosen mata kuliah analisis real kepada mahasiswa semester 6A secara langsung dalam bentuk kuis sebanyak 3 butir soal. Sumber data yang dipergunakan dalam penelitian analisis ini yaitu hasil tes responden terkait pembuktian matematik dan sumber responden yang dipilih didasarkan pada kriteria yang dipenuhinya.

\section{HASIL DAN PEMBAHASAN}

Berdasarkan hasil jawaban kuis mata kuliah analisis real diperoleh bahwa pemahaman mahasiswa dalam menganalisis teorema atau sifat-sifat aljabar bilangan real dengan soal-soal yang diberikan masih belum bisa dikatakan mampu dengan baik dalam menganalisis soal tersebut, baik mahasiswa dengan kemampuan tinggi, sedang, dan rendah. Dibawah ini akan dipaparkan model jawaban mahasiswa yang dianalisis jenis pemahamannya berdasarkan 4 (empat) kategori, yakni: 1) Kesesuaian Data, 2) Prosedur yang tepat, 3) Kelengkapan Data, 4) 
Kesimpulan Akhir. Pemahaman mahasiswa semester 6A pada kuis mata kuliah Analisis Real dirangkum pada tabel berikut:

Tabel 1 Hasil Analisis Pemahaman Mahasiswa Jenis Pemahaman

\begin{tabular}{cccccc}
\cline { 2 - 5 } Soal & $\begin{array}{c}\text { Kesesuaian } \\
\text { Data }\end{array}$ & $\begin{array}{c}\text { Prosedur } \\
\text { Yang Tepat }\end{array}$ & $\begin{array}{c}\text { Kelengkapan } \\
\text { Data }\end{array}$ & $\begin{array}{c}\text { Kesimpulan } \\
\text { Akhir }\end{array}$ & $\begin{array}{c}\text { Rata- } \\
\text { rata }\end{array}$ \\
\cline { 2 - 5 } & $\mathbf{1}$ & $\mathbf{2}$ & $\mathbf{3}$ & $\mathbf{4}$ & \\
\hline $1 . a$ & $70,27 \%$ & $52,25 \%$ & $61,26 \%$ & $64,86 \%$ & $62,16 \%$ \\
\hline $1 . b$ & $57,43 \%$ & $37,84 \%$ & $47,64 \%$ & $89,19 \%$ & $58,18 \%$ \\
\hline 2 & $76,01 \%$ & $58,78 \%$ & $67,40 \%$ & $2,70 \%$ & $51,23 \%$ \\
\hline 3 & $37,07 \%$ & $32,43 \%$ & $34,75 \%$ & $81,08 \%$ & $46,34 \%$ \\
\hline Rata-rata & $60,20 \%$ & $45,33 \%$ & $52,76 \%$ & $59,46 \%$ & \\
\hline
\end{tabular}

Hasil analisis pemahaman mahasiswa dari tabel diatas menunjukkan bentuk pemahaman mahasiswa dalam menjawab tes yang diberikan. Pada tabel hasil analsis tersebut, untuk soal nomor la, kemampuan mahasiswa pendidikan matematika 6A UMN AI Washliyah Medan dikatakan memiliki tingkat pemahaman yang sama dari segi keempat aspek pemahaman yang dianalisis. Pemahaman mahasiswa ditinjau dari: aspek kesesuaian data memiliki tingkatan sebesar 70,27\%, aspek prosedur yang tepat memiliki tingkatan sebesar $52,25 \%$, aspek kelengkapan data memiliki tingkatan sebesar $61,26 \%$, aspek kesimpulan akhir memiliki tingkatan sebesar $64,86 \%$. Sehingga, rata-rata yang diperoleh dari keempat aspek pemahaman pada soal nomor la yaitu $62,16 \%$.

Untuk soal nomor 1b, pemahaman mahasiswa ditinjau dari: aspek kesesuaian data memiliki tingkatan sebesar $57,43 \%$, aspek prosedur yang tepat memiliki tingkatan sebesar $37,84 \%$, aspek kelengkapan data memiliki tingkatan sebesar $47,64 \%$, aspek kesimpulan akhir memiliki tingkatan sebesar $89,19 \%$. Rata-rata yang diperoleh dari keempat aspek pemahaman pada soal nomor 1 b yaitu $58,18 \%$. Dalam hal ini terlihat bahwa soal nomor $1 \mathrm{~b}$, aspek kesimpulan akhir memiliki tingkatan tertinggi diantara aspek lainnya.

Selanjutnya pada soal nomor 2, pemahaman mahasiswa ditinjau dari: aspek kesesuaian data memiliki tingkatan sebesar $76,01 \%$, aspek prosedur yang tepat memiliki tingkatan sebesar 58,78\%, aspek kelengkapan data memiliki tingkatan sebesar $67,40 \%$, aspek kesimpulan akhir memiliki tingkatan sebesar $2,70 \%$. Rata-rata yang diperoleh dari keempat aspek pemahaman pada soal nomor 2 yaitu 51,23\%. Dalam hal ini terlihat bahwa pemahaman mahasiswa untuk soal nomor 2 pada aspek kesimpulan akhir masih sangat rendah dibandingkan aspek lainnya. Hal ini dikarenakan sebagian besar mahasiswa semester 6A tidak menuliskan kesimpulan akhir pada soal nomor 2 ini.

Dan yang terakhir yaitu pada soal nomor 3, pemahaman mahasiswa ditinjau dari: aspek kesesuaian data memiliki tingkatan sebesar 37,07\%, aspek prosedur yang tepat memiliki tingkatan sebesar 32,43\%, aspek kelengkapan data memiliki tingkatan sebesar 34,75\%, aspek kesimpulan akhir memiliki tingkatan sebesar $81,08 \%$. Rata-rata yang diperoleh dari keempat aspek pemahaman pada soal nomor 3 yaitu 46,34\%. 
Dalam hal ini terlihat bahwa pemahaman mahasiswa untuk soal nomor 3 pada aspek kesimpulan akhir lebih tinggi dibandingkan aspek lainnya.

Berdasarkan data diatas maka dapat disimpulkan bahwa pemahaman mahasiswa program studi pendidikan matematika UMN Al Washliyah Medan semester 6A terhadap teorema dan sifat-sifat aljabar bilangan real dikatakan masih rendah dari seluruh aspek penilaian yang dianalisis, karena rata-rata keseluruhan dari setiap aspek masih dibawah standar penilaian pada umumnya. Pemahaman tertinggi terdapat pada aspek kesesuaian data dengan persentase rata-rata sebesar $60,20 \%$ dan pemahaman terendah terdapat pada aspek prosedur yang tepat yaitu dengan persentase rata-rata sebesar $45,33 \%$.

Berdasarkan total keseluruhan dan rata-rata yang ditunjukkan, subjek yang diambil dalam penelitian ini mendapatkan hasil yang rendah. Tetapi jika dilihat hasil perorangan dari hasil kuis, jawaban mahasiswa semester 6A sangatlah beragam, ada yang pemahaman analisisnya tinggi, sedang, hingga rendah, yang masingmasing akan ditunjukkan pada Gambar 1 (P1), Gambar 2 (P2), dan Gambar 3 (P3). Berikut akan disajikan hasil pekerjaan subjek dengan pemahaman sedang $\left(P_{1}\right)$

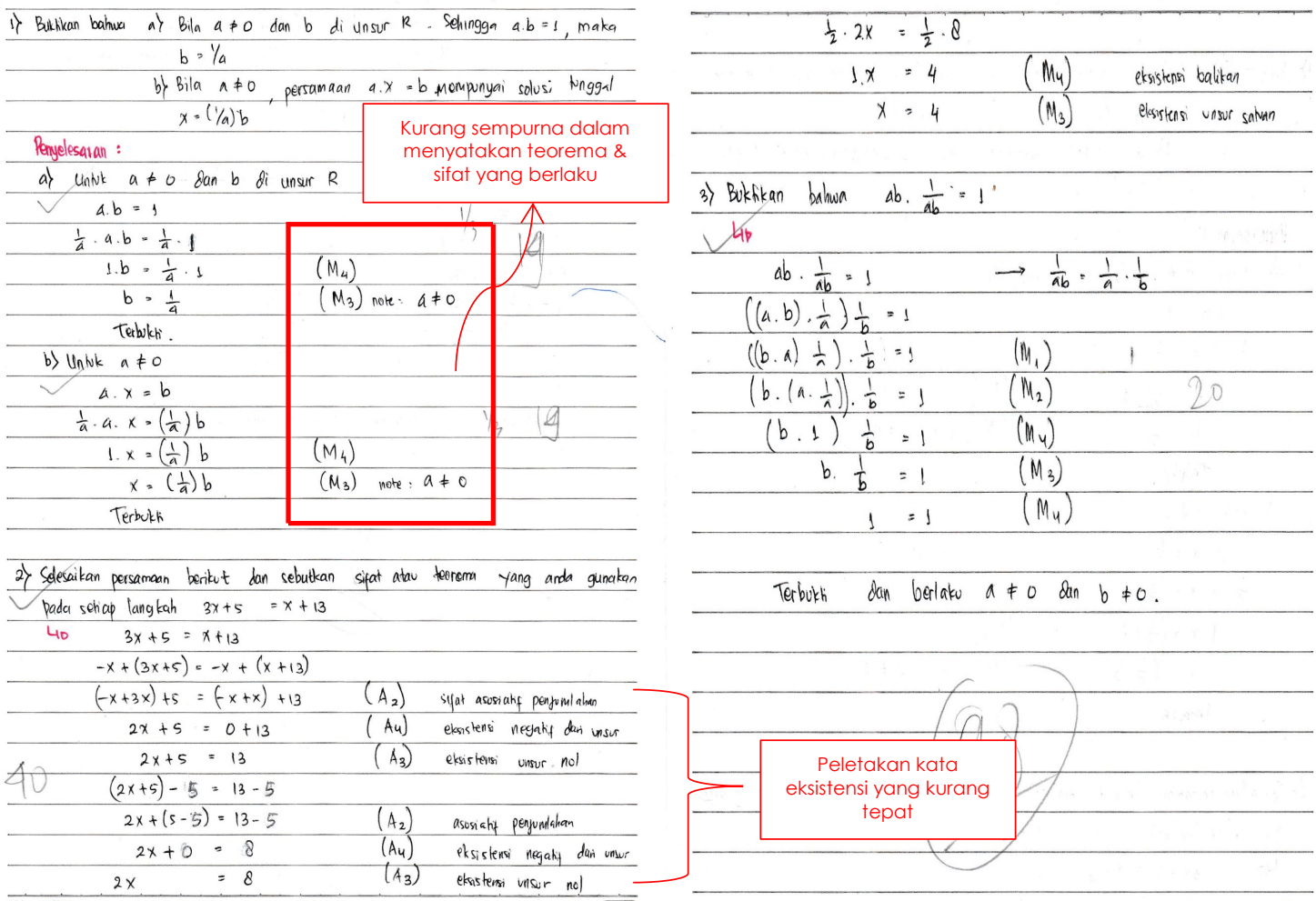

\section{Gambar 1. Hasil Jawaban Mahasiswa dengan Pemahaman Kategori Tinggi}

Dari hasil jawaban mahasiswa dengan kategori tinggi (P1) pada Gambar 1 soal nomor 1 bagian a dan b, dapat dilihat bahwa mahasiswa masih mengalami kesalahan dengan tidak menempatkan sifat-sifat maupun teorema-teorema bilangan real secara lengkap, yang seharusnya terdapat teorema 2.1.3 (b) pada bagian a, dan pada bagian b terdapat teorema 2.1.4 (b). Dan juga (P1) dalam melakukan analisis soal yang diberikan, tidak diawali dengan kata "akan dibuktikan" 
pada seluruh soal yang diberikan. Meskipun demikian, penyelesaian yang ditulis oleh (P1) memiliki tingkat penyelesaian yang hampir sempurna dibandingkan mahasiswa lainnya. Penyelesaian serupa juga ditunjukkan oleh beberapa atau sebagian kecil subjek penelitian ini.

Berikut akan disajikan hasil pekerjaan subjek dengan pemahaman sedang $\left(\mathrm{P}_{2}\right)$.

1) Buktikan Bahwa:

a) Bila $a \neq 0$ dan $b$ diunsur di $R$ Sehingga $a \cdot b=1$, maka $b=1 / a$

b) Bila $a \neq 0$, persamaan $a \cdot v=b$ mempungai solusi tunggal $v=(1 / a) \cdot b$
2) Selesaikan Persamaan berikut dan sebutkan sifat atau teorema yang anda gunakan pada setiap cangka $3 v+5=v+13$

3) Buktkan Bahwa
$a b \frac{1}{a b}=1$

penuele saian:

1) (a) $\begin{aligned} a \cdot b & =1 \rightarrow b=1 / a \\ a \cdot b & =1 \quad \text { (Ekstensi (M4) } \\ \frac{1}{a}(a \cdot b) & =\frac{1}{a} \cdot+\quad\left(M_{2}\right) \quad 1 / 3 \\ 1 \cdot b & =\frac{1}{a} \quad\left(M_{4}\right) \\ b & =\frac{1}{a} \quad \text { (Terbukti) }\end{aligned}$

\section{Gambar 2. Hasil Jawaban Mahasiswa dengan Pemahaman Kategori Sedang}

Berdasarkan hasil jawaban mahasiswa (P2) dengan pemahaman kategori sedang sebagaimana disajikan pada Gambar 2 dapat dilihat bahwa (P2) kurang paham dalam penyesuaian peletakan eksistensi negatif seperti pada soal nomor 2 dimana $3 x=x+8$ ditulis menjadi $3 x-x=x+(-x)+8$, hal ini tidak sesuai dengan kaidah peletakkan eksistensi negatif dalam matematika, dimana yang seharusnya yaitu $3 x-$ $x=x+8+(-x)$, lalu untuk selanjutnya baru bisa untuk di selesaikan. Dan pemahaman (P2) masih kurang juga terlihat dengan tidak adanya peletakkan sifatsifat serta teorema pada soal nomor 1 bagian $b$.

Dengan demikian, dapat dikatakan bahwa untuk subjek kedua kategori mahasiswa dengan pemahaman sedang: kesalahan yang dilakukan oleh mahasiswa adalah salah dalam peletakkan eksistensi negatif dan tidak adanya sifat maupun teorema pada salah satu soal yang diberikan, dan juga kesalahan yang sama dengan (P1). Berdasarkan kesalahan-kesalahan tersebut menunjukkan bahwa pemahaman mahasiswa dalam menyelesaikan soal dalam katagori sedang.

Berikut disajikan hasil pekerjaan mahasiswa dengan pemahaman kategori rendah (P3). 


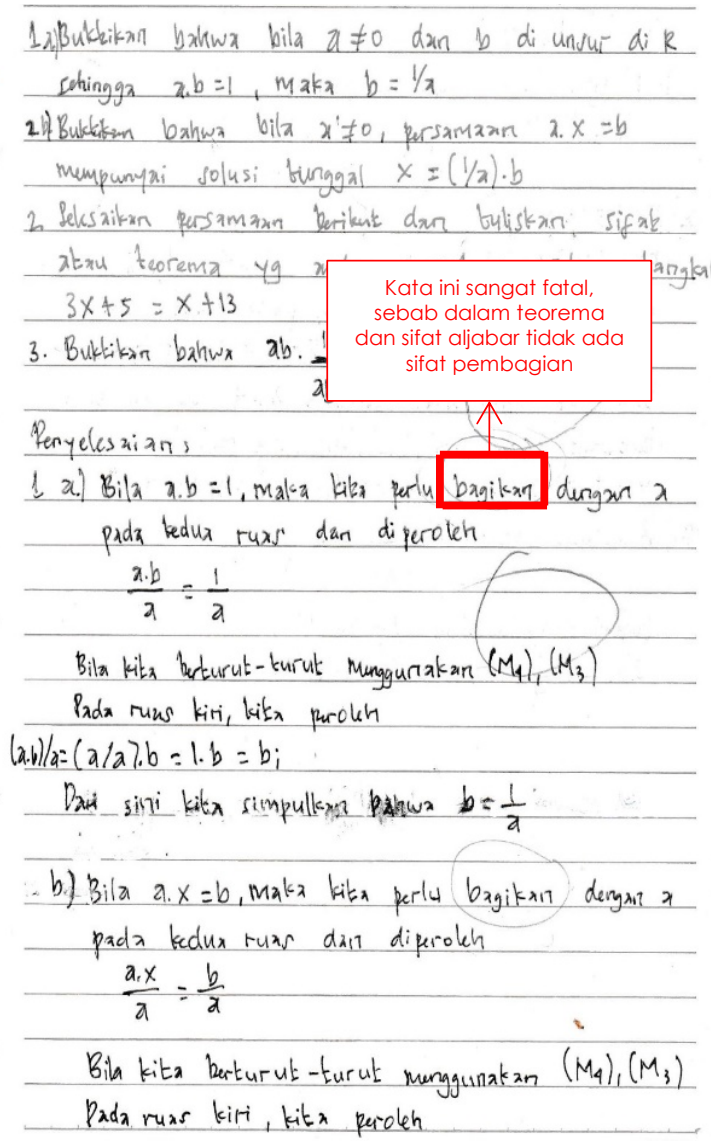

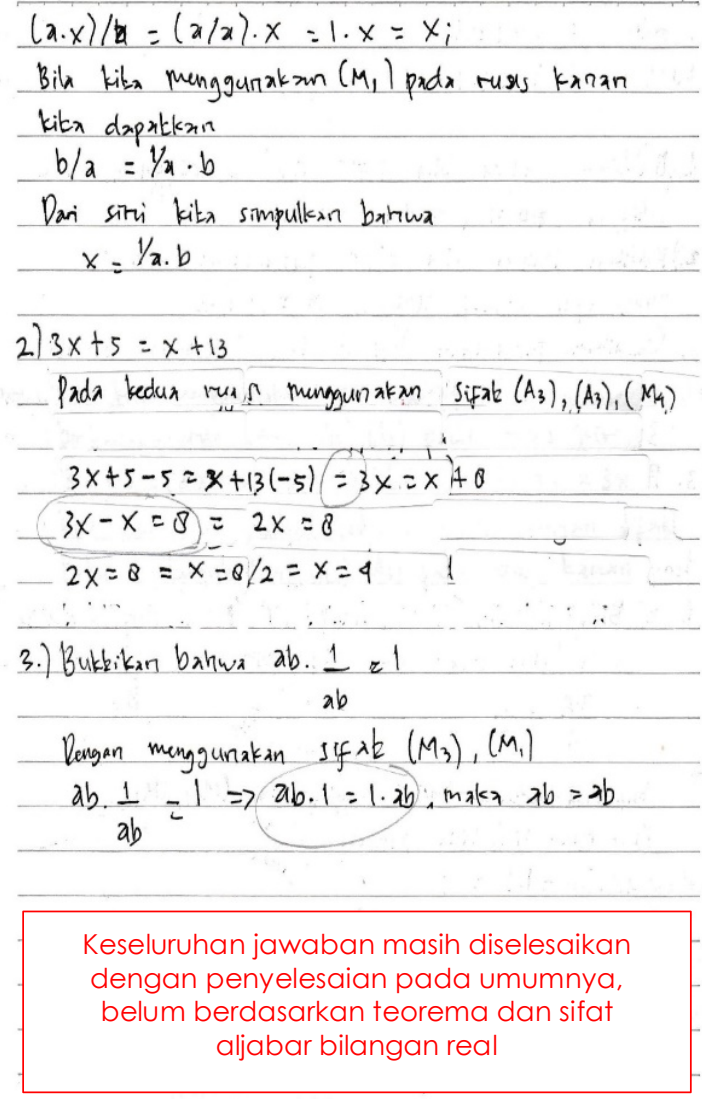

\section{Gambar 3. Hasil Jawaban Mahasiswa dengan Pemahaman Kategori Rendah}

Hasil jawaban mahasiswa (P3) dengan kategori pemahaman yang rendah pada Gambar 3 terlihat pada keseluruhan jawaban yang tidak sesuai dengan kata analisis, karena (P3) masih menyelesaikan persoalan yang ada dengan cara-cara penyelesaian pada umumnya bukan dengan analisis, dan sebagian besar mahasiswa lainnya juga memiliki cara penyelesaian yang sama seperti (P3). Hal ini menunjukkan bahwa (P3) dan sebagian besar mahasiswa memiliki pemahaman konsep teorema dan sifat aljabar yang masih sangat rendah.

Berdasarkan hasil yang telah diuraikan, terlihat bahwa pemahaman mahasiswa pada teorema dan sifat-sifat aljabar bilangan real masih dikatagorikan rendah. Hal ini terlihat dari hasil jawaban sebagian besar mahasiswa yang masih menyelesaikan permasalahan yang diberikan dengan penyelesaian pada umumnya, bukan diselesaikan secara analisis yang seharusnya. Hal ini kembali membuktikan pendapat Mutaqin, 2010 (dalam Perbowo \& Pradipta, 2017): "Mata kuliah analisis real termasuk dalam katagori mata kuliah yang dinilai sangat sulit bagi mahasiswa pendidikan matematika". Sebagian besar mahasiswa memiliki pemahaman yang kurang dalam meletakkan teorema dan sifat aljabar pada penyelesaian soal yang diberikan.

\section{KESIMPULAN DAN SARAN}

Berdasarkan hasil penelitian dan analisis data yang telah dilakukan pada mahasiswa Universitas Muslim Nusantara Al Washliyah program studi pendidikan matematika 
semester 6A, dapat disimpulkan bahwa sebagian besar mahasiswa memiliki tingkat pemahaman yang masih rendah terhadap mata kuliah analisis real terutama pada materi teorema dan sifat-sifat bilangan real. Hasil penelitian dan analisis data ini juga memperlihatkan persentase dari masing-masing aspek yang menjadi indikator pemahaman mahasiswa dalam menyelesaikan soal-soal analisis real. Pemahaman mahasiswa dilihat dari segi aspek kesesuaian data memiliki persentase sebesar $60,20 \%$, aspek prosedur yang tepat sebesar $45,33 \%$, aspek kelengkapan data sebesar $52,76 \%$, dan aspek kesimpulan akhir memiliki persentase sebesar $59,46 \%$. Persentase aspek terendah ada pada aspek prosedur yang tepat, hal ini juga terlihat pada analisis data yang telah disajikan pada gambar 1, gambar 2, dan gambar 3. Sebagian besar mahasiswa memiliki pemahaman yang masih sangat rendah dalam memberikan prosedur penyelesaian pada soal-soal tersebut.

\section{DAFTAR PUSTAKA}

Hodiyanto. 2017. Analisis Kesalahan Mahasiswa Semester V Dalam Mengerjakan Soal Pengantar Analisis Real. Jurnal Pendidikan Sains dan Matematika. 5(1).

Jamal, Fakhrul. 2014. Analisis Kesulitan Belajar Siswa Dalam Mata Pelajaran Matematika Pada Materi Peluang Kelas XI IPA SMA Muhammadiyah Meulaboh Johan Pahlawan. Jurnal MAJU (Jurnal Pendidikan Matematika). 1(1): 18-36.

Perbowo S. Kristina, Trisna R. Pradipta. 2017. Pemetaan Kemampuan Pembuktian Matematis Sebagai Prasyarat Mata Kuliah Analisis Riil Mahasiswa Pendidikan Matematika. Jurnal Pendidikan Matematika. 2(1).

Sari Kartika Christina, Mohamad Waluyo, Citra Maharani Ainur, Eka Nurhayati Darmaningsih. 2017. Menggunakan Contoh Dalam Pembuktian. Jurnal Ilmiah Pendidikan Matematika. 2(1): 1-9.

Lalu, Sucipto \& Mauliddin. 2016. Analisis Kesulitan Mahasiswa Dalam Memahami Konsep Bilangan Real. Jurnal Tadris Matematika. 9(2): 197-21 1 